\title{
Da Contabilidade à Controladoria: A Evolução Necessária*
}

\author{
Nilton Cano Martin \\ Prof. Dr. do Departamento de Contabilidade e Atuária da FEA-USP
}

RESUMO

Não pode haver ciência sem um modelo adequado de percepção e representação da realidade. Neste início do século XXI, já se tornou óbvio que no ambiente moderno dos negócios uma contabilidade gerencial, que tenha por base um modelo exclusivamente financeiro, não mais consegue propiciar as informações necessárias para dar apoio à gestão das empresas nas suas mais importantes decisões. Para manter a sua relevância decisorial, o modelo contábilfinanceiro precisa ser estendido e flexibilizado, incorporando e integrando novas dimensões e novos instrumentos de pesquisa e avaliação. Esta profunda transformação da gerencial, que levaria à moderna Controladoria, se faz integrando ao seu modelo explicativo básico, que é de natureza contábil, a identificação e a avaliação de variáveis, que têm elevado impacto sobre os resultados das empresas, tais como o valor dos produtos, os fatores ambientais setoriais e sistêmicos, os processos de trabalho e os recursos tangíveis e intangíveis mobilizados. Essas novas dimensões da Controladoria, quando associadas ao modelo contábil-financeiro, formam um quadro geral de avaliação do desempenho, que não apenas tem poder explicativo sobre o estado atual da empresa, mas também permite projeções e simulações de cenários futuros, dando lugar à exploração de oportunidades e à proteção ou hedge contra riscos, ambas de vital interesse para os stakeholders de qualquer empresa. Ao final, procura-se demonstrar quais são as novas posturas, atitudes e percepções que, ao lado de novas técnicas e instrumentos de trabalho, devem ser adotados por um contador para se transformar num moderno Controller.

Palavras-chave: Governança Empresarial; Estratégia; Análise Integrada de Desempenho; Diagnóstico Externo; Diagnóstico Interno.
ABSTRACT

Science cannot exist without an adequate model for perceiving and representing reality. In the beginning of this 21st century, it has already become obvious that, in the modern business environment, a management accounting system based on an exclusively financial model does no longer manage to provide the necessary information for supporting company management in its most important decisions. In order to maintain its relevance for decision-making, the financial accounting model must be extended and made more flexible, incorporating and integrating new dimensions and new research and evaluation instruments. Management accounting can make this profound transformation, which would lead to modern Controllership, by integrating into its basic explanatory model, which is an accounting model, the identification and evaluation of variables with an elevated impact on company results, such as product value, environmental factors characteristic of the economic sector and system, the working process and the tangible and intangible assets that are mobilized. These new dimensions of Controllership, when associated to the financial accounting model, constitute a general frame for performance evaluation, which not only has the power to explain the company's current situation, but also allows for projections and simulations of future scenarios, making room for the exploration of opportunities and the protection or hedge against risks, both of which are of vital importance for any company's stakeholders. Finally, we seek to demonstrate new dispositions, attitudes and perceptions which, together with new techniques and working instruments, must be adopted by the accountant that wants to turn himself into a modern Controller.

Keywords: Corporate Governance, Strategy, Integrated Performance Analysis, External Diagnosis, Internal Diagnosis.

*O artigo corresponde a palestra proferida no $1^{\circ}$ Seminário USP de Contabilidade realizado em outubro de 2001, na FEA-USP 


\section{Introdução}

\section{A Evolução da Contabilidade}

Para a maior parte dos autores, a função da Controladoria é fornecer aos administradores das empresas a informação que eles precisam para atingir seus objetivos, de modo eficaz e eficiente. Esta visão assume a seguinte seqüência:

$$
\text { INFORMAÇ } \tilde{A} O \Rightarrow D E C I S \tilde{A O}
$$

Toda e qualquer ciência deve possuir uma representação adequada da realidade com a qual vai trabaIhar. A representação utilizada é fundamental, porque é dela que decorre a natureza das informações que irão constituir o quadro interpretativo ou modelo de realidade dessa ciência, o qual irá fundamentar o recolhimento das informações, que, por sua vez, irão dar base às decisões. Assim, a seqüência completa é a seguinte:

\section{REPRESENTAÇÃO $\Rightarrow$ INFORMAÇÃO $\Rightarrow$ DECIS $\tilde{A} O$}

Cada modelo científico tem uma representação mais ou menos simplificada da realidade, na qual existem variáveis independentes ou causais e variáveis dependentes ou resultantes, que definem um determinado quadro de conseqüências, também chamado de estados ou resultados, que é o que o modelo procura explicar. Um modelo, em qualquer campo do conhecimento, somente terá validade representativa se proporcionar informações relevantes e suficientes para a tomada de decisões.

Quanto maior for a complexidade de um ambiente, maior será o número de fatores ou variáveis independentes que, no mundo real, estarão influenciando de forma essencial o estado final das variáveis resultantes. Tais variáveis independentes devem, portanto, estar presentes num modelo representativo viável dessa realidade. Por outro lado, quanto maior for a volatilidade ambiental, maior será a necessidade de incorporar ao modelo uma representação dinâmica da realidade que seja capaz não apenas de explicar os estados ou resultados atuais observados, mas a própria direção e intensidade das mutações futuras.

Nada mais contraproducente e até mesmo perigoso para um tomador de decisões do que trabalhar com um modelo imperfeito. Determinados modelos ficam irremediavelmente obsoletos quando se mostram incongruentes e sem capacidade explicativa em relação à realidade. O modelo de uma terra plana é dessa natureza. Outros modelos, por sua vez, podem evoluir, não só representando melhor uma realidade mais complexa através da incorporação de novas variáveis explicativas, mas também permitindo ao tomador de decisões a oportunidade de simular ou projetar dinamicamente possíveis estados ou resultados futuros. O modelo contábil-financeiro está nesta última categoria.

Mas porque o modelo contábil-financeiro precisaria evoluir? Como em qualquer outra área do conhecimento humano, as inovações em termos da contabilidade de apoio à gestão sempre aconteceram em conseqüência ou resposta a necessidades de informação. No século XV, a contabilidade de dupla-entrada foi inventada para atender às necessidades de controle dos mercadores venezianos. A partir do nascimento da revolução industrial, o primeiro sistema de custos foi criado para que houvesse uma compreensão dos recursos que estavam sendo empregados nos produtos das novas fábricas. No século XIX, a invenção da estradas de ferro e do telégrafo encorajou a dispersão das atividades econômicas em vastas extensões territoriais e testemunhou o advento de grandes companhias de distribuição, fazendo com que novos indicadores contábeis-financeiros fossem usados para avaliar o desempenho de cada um desses centros de negócio, muitas vezes separados entre si por imensas distâncias. No final do século XIX, houve o surgimento dos primeiros conglomerados empresariais que forçaram a tecnologia contábil a adaptar-se para controlar o desempenho e consolidar as atividades de empresas com múltiplas subsidiárias e unidades de negócio. Com o advento da administração científica de Taylor e Fayol, no início do século XX, foram criados padrões de tempo e quantidade para a administração da atividade industrial e a contabilidade respondeu com a criação dos sistemas de custos-padrões.

O século XX também assistiu ao imenso desenvolvimento dos mercados financeiros e à emergência das empresas abertas, que são aquelas que têm seus títulos de participação ou de empréstimos ne- 
gociados nesses mercados. Desde 19301, para salvaguardar os interesses de investidores, que, em geral, têm interesses apenas minoritários nas empresas em que aplicaram seu capital, foi totalmente codificado e altamente regulamentado pelas autoridades um ramo totalmente diferente da contabilidade: a contabilidade para utilização externa. Para atender aos seus usuários, esse tipo de contabilidade, também chamada de financeira, precisou padronizar-se ao redor de determinados princípios gerais amplamente conhecidos, que seriam as bases da preparação dos demonstrativos contábeis de qualquer empresa, de forma que qualquer investidor sempre pudesse adequadamente interpretá-los e compará-los. Entretanto, o Fisco, em todos os países do mundo, logo se aproveitou dessas regras gerais para exigir que os demonstrativos contábeis, que são a base do lançamento dos impostos sobre o lucro empresarial, também fossem preparados segundo tais diretrizes, sempre adicionando, é claro, restrições e aditivos, que somente atendem aos seus próprios interesses de arrecadação². A elevadíssima burocratização, catalogação, regulamentação, desvio do foco gerencial e subordinação aos interesses fiscais, que ocorreram nesse ramo da contabilidade nas cinco últimas décadas, fizeram com que ele se tornasse quase totalmente incapacitado para servir às finalidades da gestão empresarial. Não obstante, ao se falar em contabilidade no Brasil, mais de $80 \%$ das empresas - e um percentual igual de contadores - trabalham apenas com este tipo de contabilidade.

Isto não quer dizer que a contabilidade gerencial tenha parado totalmente de evoluir. Acompanhando o desenvolvimento da gestão empresarial que levou à introdução do TQM, da engenharia convergente, das células de fabricação, da reengenharia $e$ da introdução de um grau elevadíssimo de automação na manufatura, a contabilidade propriamente gerencial ainda conseguiu responder com al- gumas inovações técnicas, tais como o ActivityBased Costing, os custos de qualidade e o target costing. Mas, na última década do final do século XX, já havia, como há agora, uma grande e generalizada percepção de que essas últimas iniciativas e criações ainda foram bastante insuficientes, porque não conseguiram adaptar integralmente o modelo e a metodologia contábil às necessidades informativas da gestão moderna, que se faz dentro de condições de elevadíssima volatilidade e contínuas mudanças.

As causas dessa forte volatilidade são muitas e se reforçam mutuamente. O ritmo alucinante do desenvolvimento tecnológico e da liberalização do comércio internacional são dois fatores óbvios (Greider, 1998). A globalização dos mercados de produtos e de capitais, por exemplo, leva os países a ter de adaptar continuamente suas economias para conseguir maior abertura e competitividade, com diferentes graus de sucesso. Para todas as economias, especialmente as dos chamados países emergentes, esta abertura tem significado variações freqüentes e crescentes nas taxas de câmbio, juros, inflação, emprego e PIB, que têm imensas repercussões sobre todos os negócios (Hirst \& Thompson, 1997; Tavares \& Fiori, 1993) ${ }^{3}$. Por outro lado, os próprios consumidores, sujeitos a um verdadeiro bombardeio diário de ofertas concorrentes de produtos e serviços, possuem uma elevadíssima taxa de mudança de gostos, preferências e hábitos de compra (Slywotzky, 1997), que afeta as vendas e os resultados empresariais, mesmo em espaços de tempo relativamente curtos.

Em cada empresa, essa extrema volatilidade leva inevitavelmente a uma reorientação de sua administração para o nível estratégico (onde se tomam decisões sobre o que fazer: os produtos que devem ser oferecidos, os mercados que devem ser servidos, os recursos a serem mobilizados etc.), dando ênfase menor ao nível tático (onde se decide

\footnotetext{
${ }^{1}$ Essa é uma data bastante discutida pelos teóricos, mas não há como negar que a plena estruturação da contabilidade financeira ao redor dos princípios contábeis geralmente aceitos (PCGA) só veio a receber total ênfase e sistematização nos E.U.A. após o grande "débacle" da economia e das Bolsas, conhecido como a Grande Depressão.

2 Este é um fenômeno bastante conhecido dos brasileiros. Vide, por exemplo, a eliminação, por decreto, da correção monetária dos demonstrativos financeiros ocorrida com o advento do real.

${ }^{3}$ Todos esses países ditos emergentes estão nessa condição de elevada vulnerabilidade externa, como pode ser visto em 1998 e 1999 no Brasil, Taiwan, Rússia, Singapura, Malásia, Tailândia, Coréia e Indonésia. A situação da Argentina, em 2001 é o exemplo mais drástico e trágico.
} 
como fazer eficientemente o que já foi decidido ser feito: os tempos de produção, os níveis de atendimento, a qualidade dos produtos e dos serviços etc.). Quanto maior for a turbulência ambiental, tanto maior será a necessidade de reconhecer, identificar e rapidamente tomar decisões sobre tópicos de interesse estratégico. Uma das conseqüências dessas mudanças foi, por exemplo, um deslocamento das prioridades empresariais, antes voltadas para dentro e localizadas na fabricação dos produtos e nos custos industriais, para uma focalização externa no atendimento do consumidor. A definição empresarial mais fundamental, a de sua missão, começa hoje com as respostas para as seguintes questões: "Quem são os nossos clientes? Qual é o valor que atribuem aos nossos bens e serviços? Quais são as outras ofertas concorrentes de valor que eles estão recebendo? Estamos retendo ou perdendo clientes? O que podemos fazer?" Nessa nova perspectiva, importam muitas outras considerações além dos custos.

Por outro lado, um ambiente de mudanças contínuas exige que as empresas sejam reorganizadas com grande freqüência. Atividades, métodos de trabalho, formas de atuação e até divisões inteiras ficam obsoletas e devem ser reformuladas ou mesmo extirpadas das organizações, sendo substituídas por outras mais eficazes e eficientes. Todavia, uma empresa que se organiza dividindo o trabalho apenas entre especialistas funcionais, como mais de $95 \%$ delas o faz no Brasil e no mundo (Morgan, 1990; Paine \& Naumes, 1982; Drucker, 1993; Mintzberg, 1989; Marques, 1994), cria tantas e tão elevadas barreiras internas à comunicação, que elas acabam impedindo uma visão geral que possa aferir a contribuição de cada função e de cada departamento para o conjunto da empresa ${ }^{4}$. No nível da direção estratégica, onde toda decisão de aplicação de recursos implica um trade-offe um custo de oportunidade, fazse necessária a presença de generalistas unificadores e avaliadores, que sejam capazes de montar um quadro completo do desempenho organizacional, pois, sem eles, como se poderia saber se uma parte do conjunto está ainda contribuindo para os seus objetivos? Entre duas alternativas de investimentos, uma de marketing e outra da produção, por exemplo, como se poderia saber qual a que teria maior importância para a empresa? No nível dos especialistas, a decisão seria impossível: cada um deles jamais abriria mão do projeto de seu interesse. Por outro lado, uma empresa vertical com uma multidão de escalões, cada um deles recebendo os objetivos do superior e estabelecendo seus próprios objetivos para os de baixo, além de ser gravemente onerosa e perpetuadora do "status quo", simplesmente não consegue ser suficientemente rápida, próxima aos consumidores e alerta à concorrência para empreender respostas rápidas às mudanças. Esta nova realidade está exigindo que as organizações sejam estruturadas de forma diferente, através de divisões ou unidades estratégicas de negócios, que, além de uma elevada delegação de autoridade para tomar decisões rápidas, têm, em geral, uma estruturação horizontal, um número muito menor de escalões hierárquicos (vide Kilman \& Kilman, 1991; Harrington, 1995). Num grupo, as decisões finais de alocação de recursos e investimentos nas divisões se faz através de uma direção central, onde a avaliação do desempenho das divisões (e dos seus executivos) é a tarefa fundamental.

Nesse ambiente turbulento de mudanças profundas e contínuas, o exercício adequado da governança empresarial e as necessidades de informação para a tomada de decisões mudaram radicalmente na última década. As críticas que hoje se fazem à contabilidade se concentram em sua relevância nesse novo ambiente.

Embora os sistemas contábeis possam proporcionar taticamente mensurações a respeito dos custos dos recursos utilizados pela empresa, eles, por exemplo, nada dizem a respeito do porquê estratégico da utilização desses recursos e também ignoram a dimensão de valor. Todavia, as empresas vivem hoje o chamado imperativo do valor, segundo o qual as transformações produtivas executadas pelas empresas devem produzir valor através dos seus bens

\footnotetext{
${ }^{4}$ Esse fenômeno é conhecido como "a síndrome organizacional do silo" na qual, segundo as palavras de Rummler \& Brache (1990, p. 6): "Goals are established for each function independently and the activity reports are limited to these separated goals. As each function strives to meet its goals, it optimizes only its tasks and gets better and better at making its own numbers. However, this functional optimization often contributes to the suboptimization of the organization as a whole." (os destaques são dos autores).
} 
e/ou serviços (Bogliolo, 2000; McTaggart et al.,1994; Parolini, 1999). Esse valor deve ser gerado de forma concomitante e equilibrada, tanto para o cliente/consumidor, em termos de custos, tempo, qualidade e outras dimensões de sua satisfação, quanto para os investidores/acionistas, em termos de retorno financeiro de sua aplicação de recursos na empresa. O simples uso de alguns indicadores físicos de desempenho de mercado, ao lado das medidas de custos é uma tentativa absolutamente insuficiente de melhorar a qualidade informativa dos demonstrativos contábeis, porque não está vinculada a um quadro geral e consistente de representação da realidade empresarial e de aferição de seu desempenho. Além disso, se a simples verificação dos custos não habilita qualquer empresa a verificar se está efetivamente produzindo valor, também não lhe permite saber se está utilizando os recursos certos na sua atividade produtiva. A contabilidade ainda é incapaz de identificar e medir adequadamente os recursos intangíveis, que têm base no conhecimento, na experiência ou na reputação e que - hoje isto é largamente reconhecido - são os recursos verdadeiramente responsáveis pelo sucesso de uma empresa (Robert, 1998; Foss, 1997; Hitt et al., 2000). Se a posse de uma visão crítica dos recursos é hoje considerada imprescindível para a gestão empresarial, a contabilidade, em nome da relevância, também deveria possuí-la.

Por outro lado, pode-se facilmente verificar que algumas técnicas da contabilidade gerencial, como a orçamentação por centros de responsabilidade e o próprio custeio dos produtos, estão altamente comprometidas com o imobilismo e a ineficiência das estruturas organizacionais verticais montadas sobre os princípios da hierarquia e da especialização funcional (Mintzberg, 1995). É necessário à contabilidade prover-se de uma visão horizontal (por processo?) e de outras mensurações além da financeira, para poder descrever e avaliar a produtividade, não só das organizações como um todo, mas também de cada parte delas, colocando em evidência as atividades que não mais estejam contribuindo para a produção competitiva de valor. O modelo contábil-financeiro puro não consegue atingir tal objetivo e, sem poder contribuir para um dos mais ativos e necessários elementos da gestão moderna, que é a gestão de mudanças (Tuominen, 2000), está sendo progressivamente descartado por irrelevância.

No Brasil, esta situação de irrelevância da contabilidade para o apoio da administração é ainda pior. Como mais de $80 \%$ dos contadores se dedicam tão somente à contabilidade financeira ou externa, é natural que uma grande parte dos administradores acabe por vê-los quase como agentes do Fisco e, como tais, "elementos estranhos à atividade propriamente empresarial' (palavras do diretor financeiro de uma grande construtora brasileira). E é também bastante natural que, vendo a contabilidade tão somente como base de lançamento de impostos, tais administradores procurem aliviar a pesadíssima carga fiscal que atinge as empresas brasileiras (Neves \& Fagundes, 1999; Tinoco, 2001), buscando alterar, por meios nem sempre legítimos, os demonstrativos financeiros produzidos. De um modo geral, para um executivo brasileiro uma boa contabilidade é tão somente aquela que minimiza o grau de exposição tributária de sua empresa. Este estado de coisas, além de praticamente eliminar a escassa relevância que poderiam ter para a gestão os informativos contábeis ${ }^{5}$, tem sido responsável pela projeção de uma imagem social extremamente desfavorável da figura do contador e de seu trabalho.

É óbvio que as decisões empresariais precisam de informações pertinentes e relevantes para darIhes fundamento e orientação. Se os contadores não estiverem capacitados para fornecer tais informações, outros especialistas irão inevitavelmente assumir essa função. Num elevado número de grandes empresas, assiste-se hoje à disseminação dos $\mathrm{CIO}$ (Chief Information Officers), profissionais que, embora tenham uma formação mais voltada para a tecnologia da informação e menos para as realidades dos negócios, são encarregados da instalação dos grandes bancos de dados empresariais e dos

\footnotetext{
${ }^{5}$ Exceto, é claro, para os objetivos da própria gestão de impostos. Até porque a abolição da correção monetária dos demonstrativos contábeis, exigida pelo Fisco, promove, ao longo do tempo, uma total deformação das medidas financeiras do patrimônio real e dos resultados das empresas, conforme vem sendo enfaticamente demonstrado pelos trabalhos dos Professores Doutores Eliseu Martins, Ariovaldo dos Santos e Geraldo Barbieri, do Depto. de Contabilidade e Atuária da FEA-USP.
} 
software ERP. A grande difusão desses últimos, que são sistemas integrados de informação nos quais a contabilidade é apenas um pequeno capítulo (o SAP é um exemplo), poderia estar dando início, em termos mundiais, à liquidação final da contabilidade gerencial.

\section{A EVOLUÇÃO (REVOLUÇÃO) NECESSÁRIA}

Deve a contabilidade aceitar pacificamente esse destino? No âmbito empresarial, deve apenas ficar limitada ao seu uso externo, principalmente fiscal, e apenas lutar legalmente pela manutenção das prerrogativas legais dos contadores como os únicos autorizados a preparar um gênero de demonstrativos contábeis, que, de antemão já se sabe, teriam pouca ou nenhuma serventia para a gestão? Ou deve reformular-se, como sempre o fez no decorrer de sua evolução?

A resposta que está em gestação mundo afora nas empresas ${ }^{6}$, nas associações de contabilistas profissionais $^{7}$ e nas universidades está imprimindo um rumo radicalmente novo para a gerencial, que visa trazê-la para o século XXI e capacitá-la a atender as necessidades de informação num mundo de alta volatilidade. Na nova tecnologia da gerencial, o modelo contábil-financeiro continua, naturalmente, sendo o instrumento central, mas não é mais o único. Os princípios contábeis estão sendo expandidos e utilizados de forma flexível e adaptada às necessidades e situações empresariais e outros instrumentos e técnicas, provenientes de outras ciências da gestão, estão permitindo à gerencial construir, com outras métricas além da financeira, o grande quadro integrado da formação do valor e da competitividade de cada empresa, que é a grande necessidade da governança empresarial não atendida até o momento (Jensen, 1997; Prahalad, 1997).

Esta mudança programática da gerencial para fazê-la servir as empresas num mundo em contí- nua mudança envolve um novo quadro de representação da realidade, que tem cinco novas óticas, perspectivas, vertentes ou eixos de transformação, que mutuamente se influenciam e se completam, conforme o esquema da Figura 1. O primeiro eixo, o do valor, diz respeito à busca de um novo entendimento das organizações empresariais e seus objetivos. O segundo eixo, o estratégico, busca visualizar e modelar os resultados atuais e futuros de cada empresa a partir das forças ambientais. Estes dois primeiros eixos visam dar à gerencial a capacidade de diagnóstico das condições externas que são cruciais para cada negócio. O terceiro eixo, o dos processos, procura constituir uma representação mais realística da forma pela qual são articulados os recursos na formação do valor e gerados os custos. O quarto eixo, o dos insumos, se volta à avaliação da mobilização de recursos feita em cada companhia e busca determinar a sua importância relativa. Estes dois últimos eixos visam dar à gerencial a capacidade de reconhecer os pontoschaves de sua produção interna de valor e de seu vital ajustamento às condições ambientais externas. O último eixo, o de mensuração e comunicação, diz respeito à constituição propriamente dita do quadro geral do desempenho empresarial. Este deve incorporar e integrar os levantamentos e medidas de diferentes naturezas, financeiras e não-financeiras, que são obtidas com a operação dos outros eixos, e apresentar os resultados através de análises, propostas e relatórios que sejam consistentes com as condições ambientais, o quadro interno de processos e recursos e a natureza das decisões a serem tomadas.

Entretanto, antes mesmo de tratar das necessárias transformações de objetivos, metodologias e princípios, é importante pensar numa outra nomenclatura para designar o novo profissional da contabilidade gerencial. É tão distorcida e pesada a imagem social associada (injustamente?) à figura do contador, que o termo não mais serve para indicar o profissional que irá dominar e praticar o modelo e as técnicas da

\footnotetext{
${ }^{6}$ Como foi dito, o novo modelo da gerencial está em plena gestação. Todavia, algumas empresas globais, tais como a Ford, a Glaxo-Welcome, a Malle, a John Deere, a Johnson \& Johnson e a Nestlé (só para citar algumas que o autor teve a oportunidade de visitar pessoalmente) já implantaram partes consideráveis das transformações que serão descritas à frente.

${ }^{7}$ Vide os excelentes trabalhos das associações profissionais dos contadores gerenciais de diversas partes do mundo desenvolvido, tal como os EUA, a Inglaterra, a França, o Canadá, a Itália e a Austrália, que foram apresentados nos seminários do IFAC - International Federation of Accountants, em 2000 e 2001.
} 
gerencial do novo estágio evolutivo. Controller ${ }^{8}$ seria uma alternativa muito mais adequada, pelo menos no Brasil.

\section{Primeiro eixo de transformação: As organi- zações existem para a produção de valor}

A Controladoria começa com o entendimento de que todos os recursos que são mobilizados e utilizados pelas organizações têm um objetivo maior: produzir valor. A nova representação de uma organização empresarial para um Controller parte, então, da concepção de que ela executa uma transformação produtiva, na qual os recursos são convertidos em bens e/ ou serviços para os quais deve existir mercado e uma demanda econômica9 .

Figura 1: Eixos de Transformação da Contabilidade Gerencial

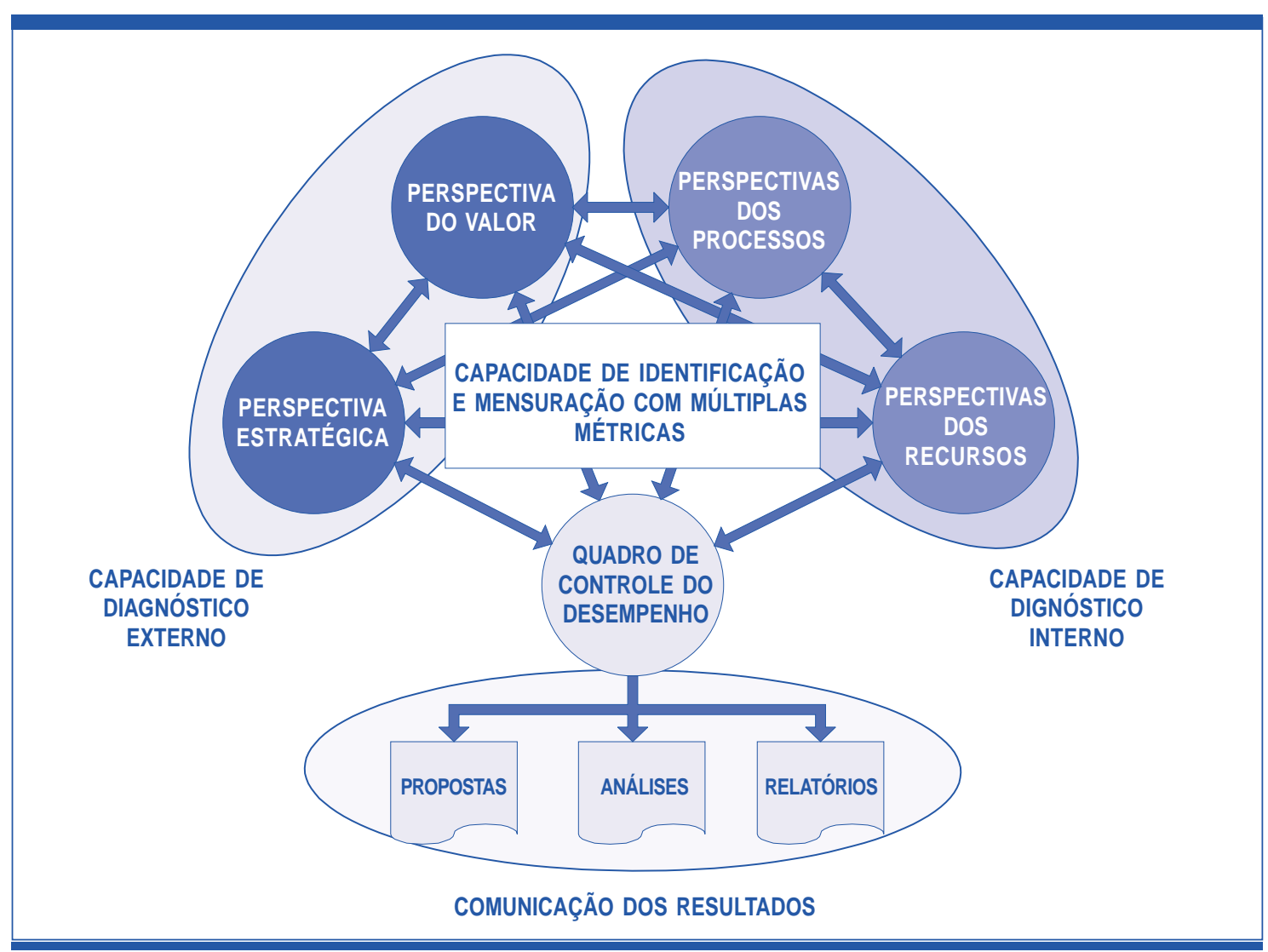

A transformação produtiva numa empresa ocorre com um consumo de recursos que gera custos e deve, com seus produtos, produzir simultaneamente valor de duas naturezas distintas (Szymanski \& Henard, 2001; Thakor, 2000; Boulton et al., 2000; Best, 2000; Scott, 1998; Tucker, 1995; Rust et al., 2001; Maklan
\& Knox, 1998; Martin \& Petty, 2000; Knight, J. A., 1998), conforme a Figura 2:

- Valor para os clientes/usuários, que consiste no conjunto de benefícios, atributos e características de desempenho, que a empresa oferece através dos seus bens e/ou serviços,

\footnotetext{
${ }^{8}$ O problema de imagem preocupa os contadores gerenciais em todas as partes do mundo e a procura de um novo termo é generalizada. Recentemente, a associação italiana dos contadores gerenciais apresentou ao IFAC o nome "dottore commerciale" e a australiana, "cognitor". Controller parece uma nomenclatura muito melhor, embora tenha sido rejeitada pela associação inglesa, porque, na Grã-Bretanha, a Controladoria estaria "demasiado próxima dos contadores a ponto de criar confusão".

9 Isto é, proveniente de indivíduos que não só tenham interesse ou necessidade dos produtos, mas que possam pagar o preço deles com a devida recuperação dos custos. Todavia, nem sempre todos custos podem ser recuperados através dos preços efetivamente praticados, o que implica numa destruição de valor para os acionistas (mas não para os clientes/usuários)
} 
pelos quais os compradores, após a devida avaliação, estão dispostos a pagar o preço de mercado.

E, ao mesmo tempo:

- Valor para os investidores/acionistas, que consiste em dar um retorno financeiro adequado aos recursos que aplicaram na empresa, compensando-os pelos riscos inerentes ao empreendimento.

O valor para os clientes é o resultado de uma relação que deve ser entendida de forma conceitual:

\section{VC $=[$ Qualidade $] /[$ Preço $]$}

A [Qualidade] na relação acima é o conjunto total ponderado de atributos e benefícios, que os clientes esperam encontrar nos produtos. A empresa será competitiva se, aos olhos dos seus clientes, seus produtos tiverem um valor maior do que o de seus concorrentes, o que poderá ser o resultado, tanto de preços menores, quanto de diferentes ou mais relevantes benefícios e atributos de qualidade que possam justificar preços maiores.

Figura 2: Produção de Valor Empresarial

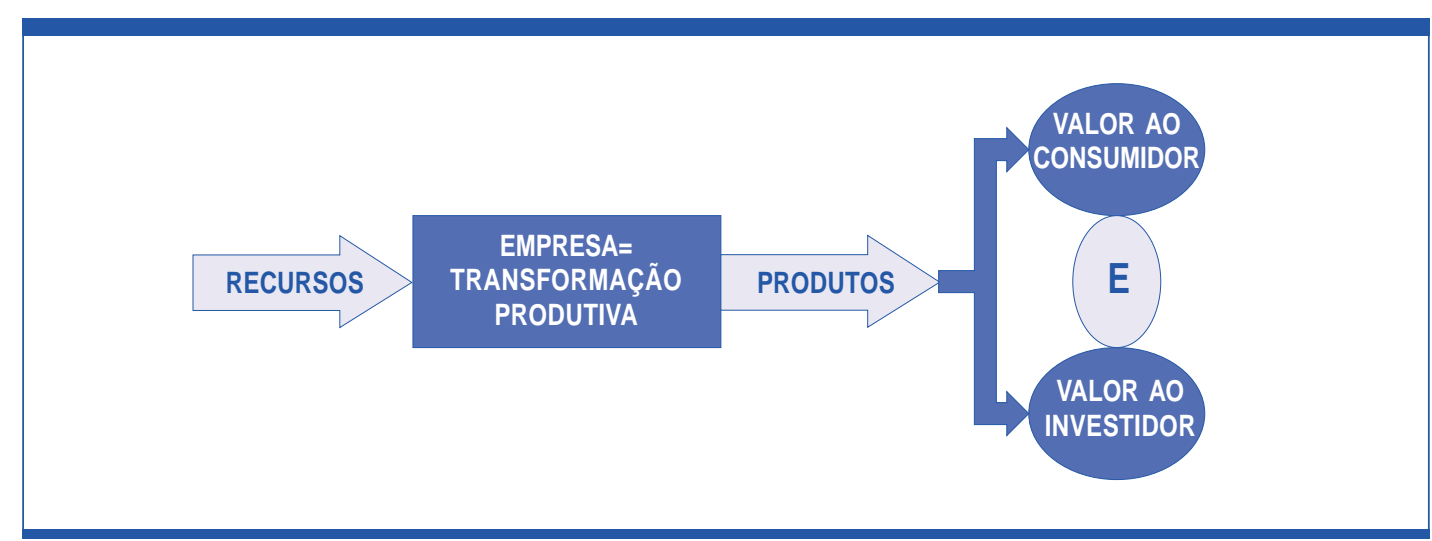

O valor para os investidores, por sua vez, tem uma expressão financeira, que é o resultado da seguinte relação:

\section{VI = [Resultados Disponíveis aos Investidores $] /$ [Investimentos Realizados]}

Uma empresa é competitiva para seus investidores, isto é, seus proprietários e demais acionistas, se, ao menor risco possível, for capaz de cumprir duas condições de remuneração do capital que investiram. Primeira: ter capacidade de prover, no curto prazo, um retorno superior à média das outras empresa do mesmo ramo de negócios. Segunda: fazer com que tal retorno, a médio e longo prazos, seja pelo menos igual à taxa de rentabilidade mínima esperada pelos investidores, que é o custo do capital próprio. Em outras palavras, uma empresa deve assegurar um fluxo estável, sustentável e adequado de retorno aos seus investidores, realizando um equilíbrio financeiro entre os objetivos de curto e de longo prazo.

Um ponto absolutamente fundamental da oferta de valor é que, em geral, uma empresa não trabalha de forma isolada no mercado. Ou seja, outras empresas também mobilizam e consomem recursos e também procuram dar uma remuneração adequada aos seus investidores, satisfazendo a mesma demanda de bens e/ou serviços. Nessas condições, cada empresa fica submetida aos imperativos da competitividade, em função dos quais se vê forçada a encontrar constantemente novos meios de executar a transformação produtiva de modo a superar os seus concorrentes. Será tanto mais bem sucedida quanto maior for o valor que produzir para os clientes e para os investidores e, mais importante, 
quanto maior for o diferencial de valor que obtiver em relação à concorrência, pois somente assim poderá assegurar a preferência dos atuais e potenciais clientes e investidores.

Se o modelo contábil-financeiro, mediante algumas modificações ${ }^{10}$, seria suficiente para medir o valor aos investidores, isso definitivamente não é o bastante para a dupla produção de valor. Deve, então, ser ampliado e reformulado para incluir e medir o valor aos clientes/usuários e a competitividade. Para elaborar seus novos demonstrativos ${ }^{11}$, a Controladoria deve efetuar mensurações diretas e indiretas de satisfação dos clientes/usuários e de posicionamento mercadológico, que seriam usadas integradamente com as medidas financeiras de retorno aos investidores na preparação de um quadro completo de avaliação de desempenho (Ray, 2000; Churchill, 1999; Malhotra, 1999).

Adotando a representação dos objetivos e metas de uma empresa a partir da dupla produção competitiva de valor, a Controladoria dá um passo essencial para entender o mundo empresarial atual. Seus levantamentos, análises e demonstrativos não mais irão padecer da visão unidimensional e unicamente financeira dos resultados das organizações. Um bom desempenho empresarial não mais poderá ser julgado apenas pela métrica financeira do retorno aos seus investidores, já que se sabe que a sustentação desse retorno no tempo (o grande objetivo os investidores) somente se dará se houver continuidade na satisfação e na preferência dos seus clientes/usuários em relação aos seus produtos.

\section{Segundo eixo de transformação: A Controladoria Deve Ser Estratégica}

Na última década, em paralelo com iniciativas em outras áreas de administração que passaram a levar o rótulo "estratégico", tais como "marketing estratégico", "manufatura estratégica", "engenharia estratégica" etc., assistiu-se, dentro da gerencial, à emergência de um movimento chamado de "contabilidade estratégica", que pretende utilizar os instrumentais clássicos, como o custeio, com o objetivo de "incremento da competitividade empresarial" (Shank \& Govindarajan, 1993). Segundo se pode depreender embora eles explicitamente não o digam - para os autores desse movimento a utilização das informações contábeis seria apenas episodicamente estratégica. Apenas um serviço adicional que poderia ser prestado em algumas especiais circunstâncias.

$\mathrm{Na}$ verdade, para atender às necessidades de gestão moderna, a Controladoria precisa ser contínua e intrinsecamente estratégica, o que ela deve realizar sem perder jamais seu caráter de apoio operacional. Para conseguir essa conexão estratégico-operacional é necessária uma postura muito mais profunda, com mudanças inclusive de caráter epistemológico. A primeira diz respeito à compreensão da própria natureza da empresa e de seus objetivos, acima discutida. A segunda, ao entendimento de que qualquer empresa sempre está imersa num ambiente volátil e competitivo com o qual interage profundamente.

Forças ambientais, tais como as que estão presentes nos mercados, na concorrência e na tecnologia, afetam diretamente os resultados de todas as firmas que se encontram em determinado setor de negócios. Forças ambientais mais gerais ou sistêmicas, tais como as políticas, econômicas, sócio-culturais e demográficas, exercem sua influência sobre todas as áreas de negócios e, por conseguinte, sobre todas as empresas situadas dentro de um país. Todos os países, por sua vez, de acordo com o seu posicionamento e estágio de desenvolvimento, são impactados pelas chamadas forças globais, entre as quais, nos últimos tempos, emergiram as duas forças poderosíssimas já citadas: a globalização dos mercados (especialmente o financeiro) e a revolução da tecnologia (especialmente da informática associada às telecomunicações).

Embora as forças ambientais sempre estivessem presentes, afetando os resultados das empresas, a contabilidade sempre abdicou de entendê-las como um problema propriamente contábil (Hatherly, 1993). Na verdade, um contador da escola tradicional poderia passar vinte anos dentro de uma empresa produzindo os demonstrativos financeiros convencionais,

\footnotetext{
10 Adotando o "cash flow accounting" ( Donleavy, 1994) e a inclusão do custo de capital pelo EVA (Stewart. 1991; Eccles et al., 2001), por exemplo.

11 Os chamados "mapas do valor" são um exemplo de inovações nesse sentido (Cleland \& Bruno, 1996).
} 
sem jamais, como contador, precisar saber algo sobre os concorrentes da empresa, a qualificação dos seus fornecedores, a necessidade de atender os clientes etc. (Franks, 1995). Entretanto, para a Controladoria esse entendimento é essencial, pois é o ambiente e suas forças que, na verdade, estão na base das estratégias, e estas correspondem a planos de ação e disposição de recursos segundo os quais as empresas procuram obter competitividade e produzir valor de forma crescente e sustentável, em interação com o quadro prevalecente e futuro de forças ambientais relevantes. A produção de valor de uma empresa deve passar por mudanças constantes, justamente porque a empresa deve sempre se antecipar e se adaptar a novas variáveis ambientais, tais como o gosto e os hábitos de compra de seus clientes/usuários, as ações de seus concorrentes em termos de qualidade ou preços, as novas perspectivas das taxas de juros e câmbio, as novas alíquotas de impostos, às novas tecnologias etc., etc. (Liautaud, 2001; Slywotzky, 1997).

Enquanto a função do contador financeiro-fiscal se preenche e se esgota com a produção dos demonstrativos contábeis-financeiros, a função do Controller é muito mais abrangente e complexa, pois cabe a ele identificar, prever, mensurar e avaliar o impacto das forças críticas ambientais sobre os resultados da empresa. Por exemplo, sem um profundo conhecimento e acompanhamento dos mercados e das forças de competitividade prevalecentes nesses mercados (Porter, 1989), como poderá explicar fatos tais como a perda de market-share, que podem implicar substanciais perdas de receitas e lucratividade? E, mais que isso, como poderá distinguir se a causa de um declínio dos resultados é decorrente de uma perda de competitividade perante um concorrente mais hábil ou de movimentos econômicos mais amplos e gerais como uma recessão? Saber diferenciar entre tais situações pode ser determinante para a seleção e implantação de planos específicos de defesa do valor econômico dos acionistas. No primeiro caso, tais planos irão enfocar apenas a volta do poder competitivo perdido em relação aos concorrentes (Reduções de custos e preços? Campanhas de publicidade ou promoção?). No segundo caso, como as causas subjacentes são sistêmicas, as estratégias deverão proporcionar um "hedge" mais duradouro da empresa perante a situação recessiva (Contração das ativida- des? Busca de maior liquidez nas vendas? Paralisação ou postergação dos investimentos?). Nota-se facilmente que é absolutamente necessário distinguir entre tais situações. Um Controller, que é, por definição, um "expert" na apuração dos resultados econômico-financeiros através do modelo contábil, ao possuir um entendimento preciso das forças que estão impactando tais resultados (mesmo quando tais forças não sejam totalmente controláveis), passa a ter uma importância absolutamente inestimável na fixação dos rumos de qualquer empresa (Hatherley, 1993).

É óbvio que, num momento qualquer, há sempre uma infinidade de forças ambientais atuando direta ou indiretamente sobre uma empresa, qualquer que seja a sua área de negócios. À primeira vista, pode parecer que a tarefa de identificar e avaliar tais forças teria tal complexidade e extensão que, na prática, seria impossível realizá-la. Não é o caso. Conforme sabem muito bem os estrategistas, em qualquer cenário ambiental nem todas as variáveis ambientais têm a mesma importância, como se poderia esperar pelo princípio de Pareto. Em cada momento, apenas um pequeno grupo de fatores (geralmente não mais do que meia dúzia e raramente mais de uma dezena) são os que efetivamente determinam a situação da empresa. São os chamados fatores críticos ambientais (FCA) (Grant, 1991).

Além de influenciar decisivamente as transformações estruturais sistêmicas ou intersetoriais, são os FCA que reconfiguram as variáveis que comandam o valor que os usuários/clientes atribuem aos produtos e as dimensões que a competitividade assume em cada ramo de negócios. Identificar, mensurar e avaliar o efeito dos FCA e das mudanças estruturais dos setores sobre a produção e sustentação do valor para os clientes/usuários e para os investidores/proprietários é, portanto, uma tarefa fundamental da Controladoria, já que tais informações são ansiosamente demandadas por qualquer governança empresarial, com exceção, é claro, das absolutamente ineptas ou alienadas.

Toda a gestão empresarial está voltada para o futuro. Fica claro, portanto, que a função estratégica da Controladoria para apoiar a gestão deve necessariamente se projetar para o futuro. Como disse Ansoff, "a função das estratégias é a de preparar no presente a empresa para que ela possa estar viva e rentável no futuro" (Ansoff, 1984). Todavia, como já disse 
um crítico, "é impossível dirigir um veículo para frente, olhando apenas para o espelho retrovisor" (Drucker, 1964), como o faz a contabilidade financeira para atender ao princípio da objetividade. Na verdade, o novo modelo contábil de representação da realidade deve estar perenemente preocupado com o desdobramento futuro dos FCA e com o futuro que está sendo "moldado" através das decisões atuais. Essa preocupação faz com que a Controladoria naturalmente busque incorporar instrumentos e técnicas de projeção e exploração futura das variáveis ambientais, tais como a técnica dos cenários e do future planning (Ringland, 1998; Godet, 1985; Bontempo, 1999). Sem tais técnicas, a orçamentação operacional e de capital de uma empresa, que faz parte das atribuições básicas de uma Controladoria, seria apenas um exercício matemático sem maiores fundamentos. Como se poderia, por exemplo, projetar um fluxo de caixa com um horizonte de 10 anos para a compra de uma máquina ou de uma empresa, sem se procurar saber como se comportarão as variáveis ambientais futuras e como estas irão afetar os resultados do investimento feito? Não se trata apenas de prever os fluxos de caixa futuros, mas saber, antes, se no futuro haverá fluxos de caixa.

Muitos poderão objetar que o exercício de projetar o futuro é fútil, já que o futuro é praticamente impossível de ser antecipado. O que deve ser considerado é que praticamente todas as decisões empresariais mais importantes precisam de informações básicas sobre suas possíveis conseqüências futuras para serem avaliadas (Modis, 1998). Esta necessidade de informações precisa, portanto, ser atendida, e cabe à Controladoria prover tais informações. Assim, embora se saiba que o futuro será sempre inexoravelmente incerto, isto não quer dizer que não deva ser entendido e explorado, o que pode ser feito incorporando ao modelo contábil uma outra dimensão: o da incerteza ou risco (Daniel, 2000; Pickford, 2001; George, 1996). Com esta, as projeções futuras passam a ser feitas em regime de risco e não mais se poderia falar, por exemplo, numa projeção de vendas de $\mathrm{R} \$ 3$ milhões para o próximo ano. Esta seria uma previsão determinística e o futuro não pode ser representado logicamente dessa forma. Como o risco implica necessariamente uma possível variação dos resultados futuros, previsões com risco sempre devem associar uma medida de dispersão dos resultados (a variância ou o desvio-padrão, por exemplo) ${ }^{12}$ a uma medida posicional ou escalar (como a média, por exemplo) dentro de uma certa distribuição de probabilidades. Desta forma, saindo de um regime determinístico para um de risco, se falaria, no exemplo, de uma distribuição normal de vendas para o próximo ano, com uma expectativa ou média de $\mathrm{R} \$ 3$ milhões com um desvio-padrão de $5 \%$.

Qual a vantagem da incorporação do risco ao modelo da Controladoria? A resposta é simples: melhora consideravelmente as informações que tal modelo passa a prover sobre a realidade e, com isso, propicia decisões melhores e mais conscientes (Doherty, 2000; Culp, 2001; Koller, 2000; Young \& Tippins, 2001). Tome-se como exemplo um empresário que acaba de tomar a decisão de investir num determinado projeto, porque, após uma análise do tipo determinístico, Ihe foi informado que ele teria uma taxa de retorno de $25 \%$ aa, a qual, quando comparada ao custo de capital dessa empresa, da ordem de $20 \%$ aa, demonstraria a viabilidade do empreendimento. Essa decisão de investimento seria tomada se o empresário soubesse que, embora a média esperada de retorno fosse de fato $25 \%$ aa, há também uma probabilidade de mais de $30 \%$ de que o projeto venha a gerar retornos inferiores a $12 \%$ aa? Um bom número de administradores, talvez a maior parte, já não aprovaria tal projeto.

A elaboração do perfil de risco de um projeto - e da própria empresa ${ }^{13}$, que é a atribuição de probabilidades a um intervalo de resultados esperados de um empreendimento, é uma metodologia de avaliação simultânea das dimensões associadas de risco e rentabilidade, que permite dar aos administradores uma informação de conteúdo infinitamente mais rico do que o que era fornecido ao se adotar uma premissa determinística de certezas totalmente dissociada da realidade. A adoção de modelos para a avaliação dos riscos empresariais é um exemplo de representações do futuro, que certamente tornam a equipe de direção

\footnotetext{
12 Essa medida de dispersão mede, na verdade, a volatilidade ou o risco associado à variável examinada.

13 A moderna gestão de riscos empresariais, que envolve sua identificação, avaliação e a aplicação de técnicas de redução ou mitigação, tal como os seguros, tem sido, em muitas empresas, como a Glaxo-Wellcome, incorporada às atribuições da Controladoria.
} 
das empresas - da qual faz parte o Controller - mais consciente e mais capacitada a tomar melhores decisões de aplicação de recursos ${ }^{14}$.

E é essa aplicação de recursos que deve ter um direcionamento estratégico básico. Como foi visto acima, para alcançar e sustentar a produção competitiva de valor, a empresa deve ter um desempenho superior ao de seus concorrentes e deve ser capaz de preservar tal vantagem. O fator essencial é a adoção de estratégias adequadas aos mercados em que a empresa compete e à natureza da concorrência que ela enfrenta. Segundo Porter (Porter, 1989) há, em última instância, apenas duas estratégias alternativas que geram vantagem competitiva:

- A estratégia de eficácia de mercado: em que a empresa compete oferecendo produtos que possuem um "pacote" de benefícios ou qualidade maior ou mais amplo, que devem proporcionar um retorno superior porque permite à empresa vendê-los a preços unitários superiores, os quais não só compensariam os custos maiores de proporcionar maior qualidade, como também trariam à empresa uma rentabilidade maior que a dos concorrentes.

- A estratégia da eficiência operacional: em que a empresa compete oferecendo produtos que, para um dado nível padrão de qualidade, têm preços (e demais custos de obtenção e uso) inferiores aos de seus concorrentes.

A grande utilidade das estratégias é que elas oferecem uma diretriz geral sobre como devem ser aplicados os recursos de uma empresa para produzir valor. Mas seria um sério erro imaginar que uma diretriz, não importa quão divulgada e claramente estabelecida, seja suficiente para dirigir a aplicação total de recursos nas empresas, já que mesmo as mais simples fazem essa aplicação com dezenas de finalidades, formas e métodos diferentes. Para controlar a transformação produtiva de uma empresa e seu alinhamento estratégico para a dupla produção de valor, a Controladoria precisa incorporar em sua representação da realidade um modelo que indique em detalhe, qualitativa e quantitativamente, a forma pela qual os recursos são efetivamente empregados no contexto das atividades empresariais.

\section{Terceiro eixo: A transformação produtiva se faz através dos processos}

Para a contabilidade gerencial, a empresa nunca foi simplesmente uma grande caixa preta. A realidade da divisão do trabalho, que existe em qualquer organização, foi apreendida pela contabilidade desde o século XIX através dos centros de responsabilidade, como já foi dito acima. Através desses centros de responsabilidades (centro de investimentos, centro de custos, centros de receitas etc.), a contabilidade busca alocar em cada um o seu consumo específico de recursos, bem como sua participação na criação de receitas. Através de um quadro geral dos centros se buscaria, então, aferir as contribuições de cada um deles, bem como as responsabilidades de sua condução.

O grande problema dos centros de responsabilidade é que eles partem de uma visão vertical e tão somente hierárquica da organização empresarial e não demonstram como efetivamente estão sendo empregados operacionalmente os recursos, nem se está havendo eficácia e eficiência nesse emprego. A realidade interna empresarial deve ser apreendida pela Controladoria de modo diferente, através da compreensão da forma específica pela qual dentro de uma organização se cria valor através da transformação produtiva dos recursos em bens e serviços. No âmbito das empresas tal transformação produtiva se faz através de conjuntos de atividades chamados processos de trabalho. Estes correspondem "a uma série de atividades interligadas, que recebem insumos ou recursos (materiais, capital, trabalho humano, informações etc.) e geram produtos (bens físicos, serviços, informações etc.), que devem ter valor para seu receptor, seja ele interno ou externo"(Watson, 1994). Tudo o que se passa numa empresa, todos seus trabalhos, recursos, pessoas e produtos fazem parte dos pro-

\footnotetext{
${ }^{14}$ Em determinados negócios, como os dos bancos comerciais, bancos de investimentos, corretoras e distribuidoras, uma Controladoria que não fosse de risco e rentabilidade simultaneamente teria muito pouco valor prático, já que a essência das instituições financeiras é intermediar riscos para obter rentabilidade (vide Brito, 2000).
} 
cessos empresariais (Cano, 1999; Turney, 1992; Johansson et al., 1993; Carr et al., 1992; Brinsom \& Antos, 1994; Morris \& Brandon, 1993; Watson, 1994). São, pois, os processos do negócio que produzem valor e geram custos, e o valor que produzem sempre deveria ser maior que os respectivos custos (Grieco \& Pilachowski, 1995).

Como os processos "constituem o elemento básico da arquitetura empresarial' (Adair \& Murray, 1992), a perspectiva dos processos é outra incorporação necessária ao modelo de representação da realidade a ser utilizado pela Controladoria, pois é somente através da interação entre os processos que se pode efetivamente descrever, localizar e quantificar detalhadamente como, numa empresa em particular:

- são gerados os produtos finais e os produtos intermediários;

- são efetivamente consumidos os recursos (recursos humanos, capital, materiais, energia, tecnologia, informações etc.) e gerados os custos e os atributos da qualidade percebida pelos clientes/usuários;

- é gasto o tempo para a execução de atividades (através dos tempos de ciclo dos processos);

- o valor pode ser destruído, através de ociosidades, desperdícios e desvios de recursos, que são originados, respectivamente, por recursos potencialmente produtivos, mas que não estão sendo utilizados; por recursos que embora empregados produtivamente, são utilizados acima do mínimo necessário; e, finalmente, por recursos desviados, fraudulentamente ou não, de sua finalidade produtiva.

As estratégias adotadas por uma empresa levam a diferentes configurações do seu sistema produtivo, o que significa a constituição interna de conjuntos articulados de processos que devem dar suporte ao direcionamento estratégico selecionado. Um grupo específico desses processos, combinados e integrados, tem a responsabilidade de executar todas as operações que produzem os bens e serviços da empresa. Esse conjunto articulado de processos é chamado de rede de valor. Os demais processos da empresa, que não estão envolvidos diretamente na criação de valor para os clientes e estão mais ligados à sustentação, à integridade e à segurança da organização como um todo, constituem os processos subsidiários ou de suporte (Davenport, 1993).
A Controladoria deve efetuar um efetivo controle dos processos, o que ocorre com a sua identificação, o mapeamento de suas articulações e subdivisões e a mensuração do seu desempenho e de sua consistência estratégica, através de uma métrica mista, composta por medidas financeiras dos custos, associadas a medidas de qualidade, de tempo (Anupindi, 1999; Kock, 1995) e de eficácia competitiva. Este controle deve ser abrangente, compreendendo tanto a rede de valor como os processos de suporte, porque de nada adiantaria a empresa tentar ganhar uma vantagem competitiva através de uma redução do consumo de recursos na manufatura, por exemplo, e ver tal vantagem dissipada através de um gasto ineficaz de recursos no suporte de informática ou no marketing.

\section{Quarto eixo: Os recursos constituem a base da competitividade}

A principal razão pela qual a Controladoria deve focalizar os recursos é que os lucros são, em última instância, o resultado do emprego dos recursos mobilizados por uma empresa, seja por aquisição, seja por qualquer outra forma de contratação ou mobilização. Os lucros de uma firma sempre são derivados de duas fontes: a atratividade específica de um determinado setor de negócios no qual a empresa está operando ou pela vantagem competitiva conseguida sobre os demais firmas de seu setor. Pode-se demonstrar, todavia, que essas fontes de lucro tem sua origem primeira nos recursos empresariais (Grant, 1991; Collins \& Montgomery, 1995; Foss, 1997).

Tome-se o caso da vantagem competitiva. Numa empresa, a capacidade de estabelecer uma vantagem de custos é proveniente, por exemplo, da posse de plantas de produção eficientes, de uma tecnologia superior, de fontes de suprimento de matérias-primas de baixo custo, de licenças governamentais exclusivas ou mesmo de vantagens locacionais que lhe permitam acesso a mão-de-obra de baixo custo ou uma proximidade dos mercados consumidores. A vantagem da diferenciação, de maneira semelhante, é baseada na propriedade ou no controle de determinados recursos, tais como marcas, patentes, rede de distribuição etc. Vê-se, assim, que se os retornos sobre os investimentos num negócio, quando são superiores à média, resultam de uma vantagem competitiva, a qual, por sua vez, decorre de recursos que foram mobiliza- 
dos de forma superior. Se esses recursos se exaurirem, se tornarem obsoletos ou se tornarem acessíveis a outras firmas, os retornos obtidos de forma superior entram em declínio ou simplesmente desaparecem.

Para a Controladoria interessa saber quais dentre os recursos empregados pela empresa são os que efetivamente lhe conferem vantagem competitiva. Essa tarefa deve começar por um inventário dos recursos de diferentes tipos que a empresa mobiliza em suas atividades. Alguns desses recursos são fungíveis, como os materiais e a energia, e desaparecem ou são consumidos no próprio ato da transformação produtiva. Outros, porém, são utilizados repetitivamente nessa transformação e, por isso, constituem o que se chama a base permanente de recursos de uma empresa. Estão nesta última categoria os edifícios, os equipamentos, os recursos humanos, a tecnologia etc. É a base permanente de recursos no âmago dos processos, que confere a uma empresa capacidade produtiva, tanto em termos do volume de bens e serviços que pode produzir e distribuir, como também em termos da qualidade, custos e tempos de operação.

$\mathrm{Na}$ base permanente de recursos pode-se distinguir os recursos tangíveis e os intangíveis. Os primeiros são os mais fáceis de identificar e avaliar. Os recursos financeiros e os ativos físicos são perfeitamente reconhecidos nos demonstrativos contábeis e há regras há longo tempo estabelecidas para avaliá$\operatorname{los}^{15}$. Entretanto, é bem conhecida a tendência dessa avaliação contábil, feita pelos custos históricos, de obscurecer e omitir informações de relevância estratégica, bem como de estabelecer para os ativos empresariais valores sem muito significado ${ }^{16}$. Certamente o balanço contábil pode ser um começo, mas a Controladoria deve ir muito além e verificar, atrás dos números contábeis, fatos e informações a respeito dos recursos empresariais tangíveis que tenham importância para a produção competitiva de valor.
Uma avaliação estratégica dos recursos tangíveis pela Controladoria levaria a responder duas questõeschaves da chamada redução estratégica de custos (REC) (Cano, 1999):

- Quais são as oportunidades que existem de economizar no uso de recursos financeiros, bem como nos estoques de materiais e ativos fixos?

- Quais são as possibilidades de um emprego mais lucrativo dos ativos existentes?

Responder à primeira significa encontrar formas de envolver um volume menor de recursos para dar suporte a um mesmo volume de negócios ou usar o mesmo volume de recursos para um volume maior de negócios. Responder à segunda significa incrementar a lucratividade de um determinado volume de recursos, quer empregando-os de uma forma mais produtiva, quer transferindo-os para um atividade mais rentável, quer, ainda, vendendo-os para outras empresas. Boa parte de todo o movimento de recuperação e reestruturação de empresas nas últimas três décadas tem feito um uso intenso das metodologias da REC, que estão exaustivamente discutidas e sistematizadas na literatura sobre administração estratégica (Hitt et al.,1999; Pearce \& Robinson, 1997), mas que são ainda quase inexistentes na literatura da contabilidade gerencial.

Os recursos intangíveis constituem um problema ainda maior para a Controladoria, pois se até certo ponto eles são invisíveis para contadores e auditores, cada vez é mais reconhecida a sua importância central para a obtenção de vantagens competitivas. Para identificar e avaliar os recursos intangíveis devese, em primeiro lugar, distinguir entre os que têm uma base humana daqueles que têm origem na imagem, na reputação ou no conhecimento codificado de uma empresa ${ }^{17}$. Enquanto as pessoas são claramente tangíveis, suas habilitações, conhecimento, experiência própria, raciocínio, bem como as suas capacida-

\footnotetext{
15 Os recursos tangíveis que são objeto de aquisição obrigatoriamente figuram entre os ativos contábeis. Entretanto, quando a empresa mobiliza ativos, cujo uso ela contrata através de operações de aluguel, "leasing”, alianças, acordos de "joint ventures" etc., não está absolutamente garantida a sua inclusão nos demonstrativos contábeis, nem mesmo nas notas explicativas.

16 A avaliação pelos custos históricos torna os balanços apenas uma "coleção de saldos contábeis", que têm pouco ou nada a ver com os reais valores de mercado ou de potencial produtivo que esses ativos possuem (Reekie et al., 1991).

17 O conhecimento codificado é aquele que já se encontra incorporado ao "know-how" da empresa e que ela não perderia, mesmo se não pudesse mais contar com as pessoas que o criaram. Uma fórmula química para a produção de um medicamento, é um exemplo desse conhecimento codificado.
} 
des de liderar e tomar decisões são absolutamente intangíveis. Os intangíveis de base humana podem ser levantados através de seu desempenho no trabalho e do histórico de suas experiências e de suas qualificações. Mas estes indicadores são extremamente pobres para avaliar o potencial das pessoas. O que torna a identificação e a avaliação ainda mais difícil é que os indivíduos trabalham juntos, em tarefas ou funções que se superpõem, onde nem sempre é possível observar diretamente a contribuição de cada um para o desempenho geral da organização. Não há ainda soluções finais, nem instrumentos acabados de Controladoria para medir o valor dos intangíveis de base humana. Todavia, algumas tentativas recentes são bastante promissoras (Lev, 2001; e PeopleSoft , 2000).

Em relação aos intangíveis de base não-humana há também uma certa indefinição final sobre como avaliá-los competentemente. As metodologias existentes são apenas aproximadas e a maioria delas fundamentadas no "valor de mercado". Para a revista Business Week (edição de 6/8/2001), por exemplo, seguindo a linha de diversos teóricos, o valor de uma marca estaria na diferença entre o valor total da capitalização dessa empresa (valor das ações, ao preço de mercado) e o valor contábil (book value) de seu patrimônio líquido. Além da base teórica frágil (a teoria dos mercados eficientes ${ }^{18}$ ), este valor é visivelmente exagerado, porque tende a atribuir a um único intangível (a marca) aquele que seria o produto de um grande conjunto de intangíveis, humanos e não-humanos.

Para uma Controladoria, o ciclo completo de seus trabalhos em relação a qualquer ativo deve ir da identificação à comunicação, passando pela mensuração e pela avaliação (Azzone et al., 1995). Todavia, mesmo que este ciclo não possa ainda ser totalmente executado no que diz respeito aos intangíveis por falta de métodos eficazes de mensuração, nem por isso deixaria de ser relevante o simples reconhecimento da importância crítica que alguns deles têm para determinados negócios. Identificar tal importância constitui, por si só, um elemento informativo de alta significação para apoiar algumas decisões empresariais (Parr, 1991; Smith, 1999) e auxiliar a composição do grande quadro de avaliação de desempenho, que é a matéria do nosso próximo tópico.

\section{Eixo de Síntese: A avaliação de desempenho deve ser integrada}

Falando num seminário relativo à governança, Prahalad, o grande teórico das estratégias, disse o seguinte: "o grande problema da governança empresarial, tanto a externa (efetuada pelos acionistas e pelo Board que os representa) como a interna (efetuada pelos diretores executivos), é que ainda não existe um quadro totalmente estruturado e completo de avaliação do desempenho empresarial num determinado momento e, muito menos, um que nos permita avaliar a sustentação futura desse desempenho" (Prahalad, 1997).

A simples razão pela qual esse quadro ainda não foi construído é que todas as informações existentes numa empresa e que seguem para o executivo principal ou para o Board são fragmentadas, isto é, são preparadas a partir das óticas especiais e parciais das diferentes áreas funcionais de onde provém e, o que é pior, são freqüentemente comunicadas com o jargão específico dessas áreas. Essa é uma deficiência bastante conhecida das organizações estruturadas com base em especializações funcionais (mais uma!), que, não obstante, é a prevalecente em mais de $95 \%$ das empresas do Brasil e do mundo, como já foi dito. Assim, as informações provenientes de marketing ou produção, por exemplo, são veiculadas para o executivo principal, tendo em vista os limites do conhecimento e dos interesses estreitos dessas áreas, sem qualquer visão integrada da empresa ("síndrome do silo"), embora, como é de praxe, cada uma dessas áreas quase sempre esteja falando em nome da empresa como um todo (Mace, 1986). É fato notório que

\footnotetext{
18 A teoria dos mercados eficientes, que já vinha sendo hostilizada por uma série de teóricos, viu-se recentemente quase totalmente invalidada pela incontestável "bolha" que afetou (alguns dizem que ainda está afetando!) os preços das ações em Wall Street, especialmente nos últimos cinco anos. Uma "bolha de mercado" representa uma superavaliação sistemática dos preços das ações. Para a teoria dos mercados eficientes a existência de uma "bolha" é impossível, mas para a moderna teoria do "behavioral finance" uma "bolha" não só pode acontecer, como também tem alta probabilidade de ocorrer em determinadas condições de mercado (Goldberg \& Nitzsch, 2001 e Shleifer, 2000).
} 
este fluxo fragmentado de informações coloca uma grande pressão sobre o executivo principal. Este passa a ter a árdua missão de ser o único integrador e produtor de uma representação global da empresa, a partir de um fluxo de informações parciais, específicas, inconsistentes e sem sincronização, proveniente das diferentes áreas funcionais. Se se considerar que esse executivo é sempre originário de uma determinada área funcional da empresa e, como tal, portador da visão empresarial particular dessa área, é fácil concluir que sua missão de sintetizador e elaborador do quadro geral de desempenho da empresa é quase impossível. Como disse Prahalad, as limitações da governança empresarial resultam das terríveis deficiências desses quadros.

Esta é a grande oportunidade da Controladoria. A partir do modelo contábil-financeiro, que já é um modelo de síntese, é possível elaborar modelos de representação da realidade empresarial muito mais complexos, gerais, integrados, fundamentados e voltados para o futuro e com eles quadros mais completos de desempenho. Foi o que fizeram Kaplan \& Norton com seu balanced scorecard (Kaplan \& Norton, 1996; Kaplan \& Norton, 2001), embora seu modelo, que sob muitos aspectos é notável, deva ser entendido apenas como um ponto de partida e ser expandido (incluindo indicadores de mudanças estruturais), adaptado para cada tipo de negócio (já que cada setor tem FCA externos próprios) e especificado para cada empresa (já que cada empresa tem pontos críticos internos peculiares, que são resultantes da sua configuração particular das estratégias $>$ processos $>$ recursos e de seu posicionamento perante os mercados e os concorrentes).

Embora este trabalho não possa conter mais do que um delineamento extremamente geral e resumido de como seria tal quadro completo de desempenho (vide Figura 3), ele teria três componentes principais: (a) diagnósticos estratégicos; (b) levantamento dos objetivos/metas, estratégias e projetos atualmen- te em curso; e, finalmente, (c) análise de desempenho propriamente dito.

\section{1) Objetivos, metas e diagnósticos estratégicos}

[a] Objetivos e metas: Para esta parte do quadro geral de representação da empresa, a Controladoria deve saber, a partir de consultas à governança externa e interna: (1) Os participantes relevantes ou PR (stakeholders), que devem ser objeto de atendimento prioritário pela empresa. Já se discutiu que os dois PR prioritários ou polares são os clientes/usuários e os acionistas/proprietários. (2) As metas quantitativas específicas para a produção de valor para cada um dos PR prioritários da empresa. Uma meta financeira essencial é, como já foi dito, o custo de capital dos investidores/ acionistas. Para os clientes/usuários uma meta vital sempre será o porcentual de clientes satisfeitos.

[b] Diagnóstico externo dos FCA e das principais tendências das mudanças que estão ocorrendo no setor de negócios e como estão afetando a empresa e seus concorrentes. O ponto-chave aqui é acentuar as possíveis ameaças (sobre o mix de produtos, sobre a atuação mercadológica, sobre os canais de mercado etc.), bem como as oportunidades (novos mercados, novos negócios, novos produtos etc.), que poderão estar surgindo.

[c] Diagnóstico interno, com base nos processos e nos recursos deve-se identificar e medir os pontos críticos em relação aos processos (ociosidade, improdutividade etc.) e aos recursos (ativos estratégicos e seu aproveitamento), localizando omissões, ausências, falta de incentivos, etc., que poderão fazer com que a empresa esteja preparada (ou não!) para aproveitar as oportunidades ou se defender das ameaças ambientais. 
Figura 3: Controladoria do Valor: Esquema Geral

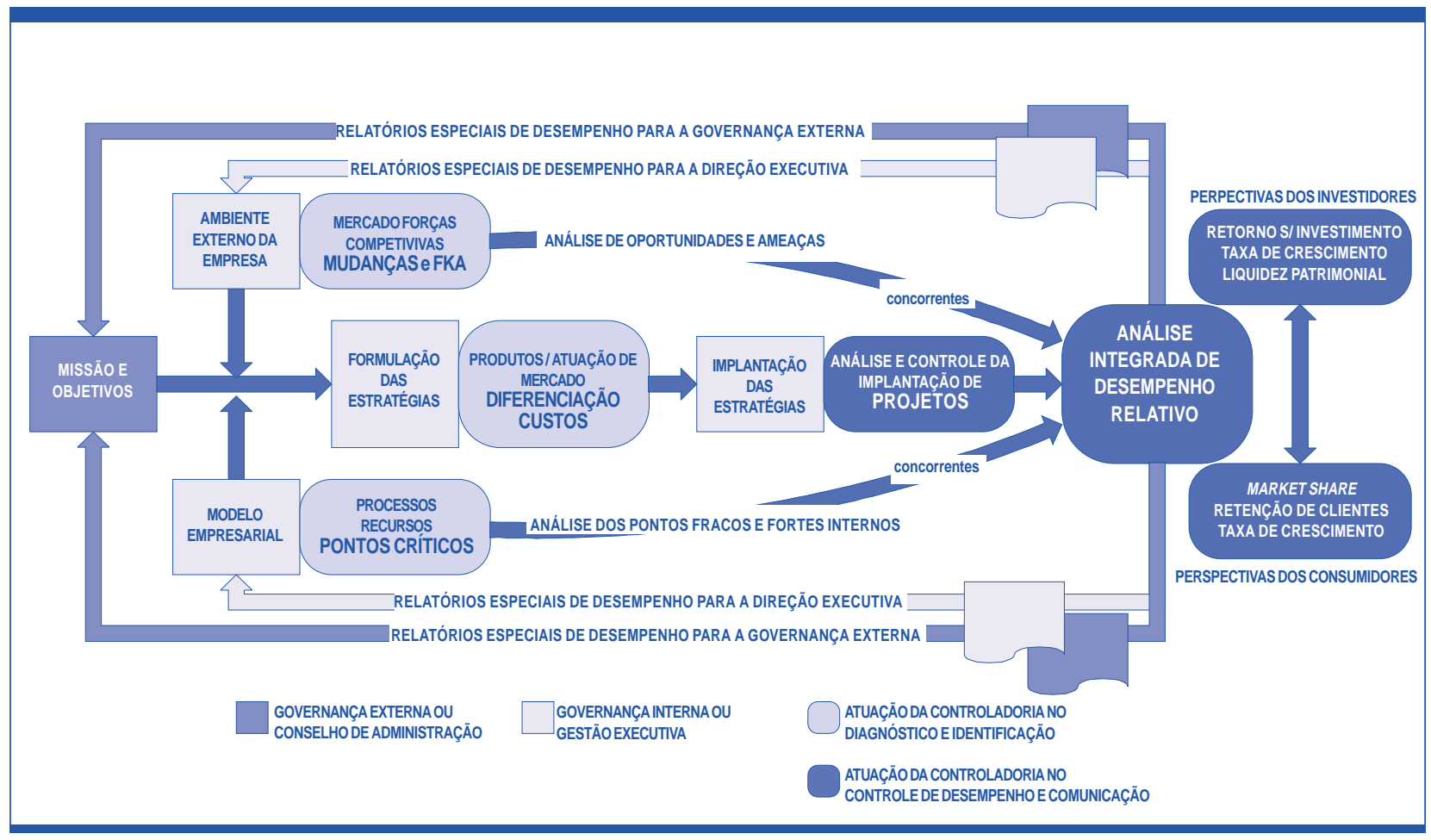

(2) Análise de desempenho relativo. Com os elementos recolhidos na etapa (1), a Controladoria passa, então, a executar a análise de desempenho propriamente dito, que consta de duas perspectivas e dois horizontes de planejamento. Como foi dito, sempre haverá em cada empresa pelo menos dois stakeholders prioritários, cuja demanda sobre os resultados e sobre a produção de valor a empresa deve satisfazer simultaneamente e em equilíbrio: os clientes/usuários, de um lado, e os investidores/acionistas, de outro. Não cabe aqui discutir todo o imenso cabedal metodológico hoje já existente, que capacita uma Controladoria não só a compilar os dados e efetuar as medidas da produção de valor para cada um dos seus $P R$, mas também a verificar a sua competitividade face aos concorrentes. Com a localização específica, nos processos e nos recursos, das ociosidades, das improdutividades, das inconsistências, das omissões, dos custos excessivos etc., que poderiam estar destruindo o valor e a competitividade da empresa, as medidas de desempenho passam a ter um caráter estratégico fundamental.

Não basta, todavia, efetuar uma análise de desempenho focalizada apenas no presente e na comparação com os concorrentes. Para buscar uma posição superi- or de competitividade, não é suficiente para uma empresa comparar seu desempenho com a liderança de seu setor em termos da qualidade dos produtos, tempos de ciclo, custos, faturamento por número de empregados, níveis de produtividade etc. O seu objetivo ao fazer isso é colocar-se numa posição no mínimo igual aos "melhores da classe". É claro que esse exercício pode ser produtivo, como base da REC, por exemplo, para a eliminação de ociosidades e desperdícios. Este tem sido, afinal, o foco de boa parte das reestruturações e reengenharias empresariais havidas nas últimas três décadas. Mas um quadro de avaliação de desempenho não pode se concentrar apenas em informações sobre diferenciais de "performance", já que eliminar tais diferenciais é uma condição necessária mas não suficiente da criação superior de valor.

Se não todos, a maior parte dos problemas de desempenho nas empresas resulta tanto de uma má gestão dos seus parâmetros de desempenho relativo em relação aos concorrentes, como de respostas insatisfatórias ou tardias às mudanças estruturais em seu próprio setor de negócios. São os diagnósticos estratégicos externos que permitem à empresa verificar as tendências ambientais que podem estar provocando mudanças estrutu- 
rais no seu setor de negócios. Uma parte importante da análise de desempenho sempre será, pois, a exploração do futuro da empresa em regime de risco e a verificação, através de cenários, da forma pela qual os seus resultados poderão ser impactados pelos fatores de mudança setorial, especialmente os tecnológicos e os de mudança das preferências dos consumidores/usuários. O controle da implantação das estratégias, através da análise de viabilidade estratégico-financeira de projetos de investimento, faz parte deste controle de desempenho num horizonte futuro, que jamais deve ser descurado pelos Controllers.

(3) Comunicação. Poucos, infelizmente ainda muito poucos Controllers se preocupam efetivamente com o aspecto da comunicação dos resultados de seu trabaIho. Não obstante, esse é um das facetas mais importantes de suas modernas atribuições. Como um Controller não tem poder para tomar decisões, ele precisa produzir e dar as informações pertinentes e relevantes a outros executivos, de forma a provocar decisões corretas e dentro do prazo adequado. Apesar de ele mover-se num mundo de especialistas ${ }^{19}$, suas análises, propostas e demonstrativos não deverão, pois, padecer dos jargões típicos de especialistas, que, por não serem entendidos, jamais serão utilizados de forma apropria$\mathrm{da}^{20}$. Por outro lado, deve ficar claro que o valor de uma informação pode ficar rapidamente obsoleto, se tal informação não for veiculada antes que tenha passado a oportunidade de tomar decisões sobre a situação ou o fato que está sendo reportado. Jamais um Controller deve perder a oportunidade de ser relevante para poder ser mais preciso ou mais profundo. Esta é uma das pragas que sempre assolaram os contadores, que de forma alguma deve também cair sobre os Controllers.

O ponto vital da comunicação da Controladoria é a confecção de relatórios de desempenho para a governança empresarial, como se pode verificar na Figura 3. Esses relatórios devem ter elementos que permitam, através dos resultados, aquilatar 0 direcionamento estratégico e, dessa forma, permitir aos principais executivos (governança interna) e ao Board (governança externa) avaliar, de um lado, os objetivos e metas da empresa e, do outro, as estratégias e a própria ação dos administradores que as formularam e as implantaram (ou não!). Aqui é pertinente um comentário: alguns teóricos e muitos executivos não aceitam, em hipótese alguma, que um Controller possa enviar relatórios diretamente ao Conselho de Administração, "por cima das cabeças dos executivos". Todavia, quando a comunicação Controladoria-Conselho não existe, ocorre uma grave deficiência no fluxo de informações para a governança externa, que, na prática, já tem outros obstáculos enormes para o exercício de suas funções com um mínimo de eficácia. Para superar o impasse, basta assegurar que os relatórios que são preparados pela Controladoria para envio ao Board sejam remetidos simultaneamente para a Direção executiva. Ficaria, assim, preservada a independência dos Controllers, sem quebrar a hierarquia e o espírito de equipe que devem existir em todo corpo diretivo empresarial ${ }^{21}$.

\section{Conclusão: A Grande Travessia da Contabilidade à Controladoria}

A Controladoria deve ser vista como o pináculo da carreira do contador numa empresa e o caminho natural de sua ascensão à Direção. Afinal, no mundo todo, não é pequena a proporção de Controllers que se tornaram os principais executivos (CEO) de suas empresas ${ }^{22}$. Todavia, há uma questão anterior de vital importância: como os contadores podem tornar-se Controllers? Não são pequenos os obstáculos. Um deles, como já foi discutido acima, decorre

\footnotetext{
19 Apesar de todos os seus inconvenientes, os especialistas consideram que a organização com base em especialistas funcionais ainda deve ter uma longa vida (Enriquez, 1992; Keidel, 1995).

${ }^{20}$ Esta é uma outra grande, constante e pertinente crítica feita aos Contadores.

21 Esta comunicação com o Board traz, por outro lado, uma extraordinária valorização do trabalho da Controladoria. Um executivo não constrangido pela governança externa pode sempre diminuir a importância das informações veiculadas por um Controller, mesmo que este seja extremamente competente no sentido estratégico do termo. Numa hipótese extrema, pode até descartar tais informações inteiramente, configurando a chamada "maldição da Controladoria" (conhecer e não poder agir). Entretanto, se tal executivo souber que seu comportamento decisorial está sendo avaliado pelo Board através dos relatórios de desempenho da Controladoria, vai pensar duas vezes antes de descartar ou desconhecer tais relatórios.

22 A revista Fortune numa pesquisa sobre a origem dos CEOs das "One Thousand", as 1.000 maiores empresas americanas, admitiu sua surpresa ao verificar que eram da Controladoria que provinha a maior parte deles (aproximadamente $27 \%$, contra $21 \%$ de Marketing e $19 \%$ da Produção). Um exemplo de Controller bem sucedido como CEO foi Welch da General Electric, um dos executivos mais talentosos e de maior projeção no cenário internacional, nos últimos 15 anos (Welch se aposentou da GE em 2001).
} 
da própria visão que, ao menos do Brasil, os dirigentes de empresas têm do Contador. (Porque, a não ser numa empresa especializada em auditoria ou planificação tributária, se daria oportunidade a um expert em demonstrativos financeiros para fins fiscais de fazer parte da equipe de Direção?) Mas o maior obstáculo, na opinião do autor, vem da própria postura, percepções, atitudes e excesso de especialização na área tributária que caracterizam a "mentalidade típica do contador fiscal", que é altamente limitante e está bastante generalizada entre os contadores, o que, de certa forma, é natural, uma vez que, como já foi dito acima, mais de $80 \%$ deles no Brasil se dedicam exclusivamente à contabilidade financeira. Esta mentalidade é o fator que, de fato, mais está restringindo a sua capacidade de se tornarem Controllers ${ }^{23}$. A Figura 4 demonstra as características que distinguem a Controladoria da Contadoria Financeira.

As transformações da contabilidade gerencial que estão ocorrendo no mundo e que procuram colocá-la em sintonia com as transformações recentes no panorama mundial dos negócios têm imensas implicações para o ensino e a formação de Controllers. A mais importante delas é que, se se deseja preparar Controllers, não se deve mais formar especialistas em contabilidade, já que as atribuições da Controladoria abrangem a contabilidade financeira ou externa, mas vão muito além. O Controller, como foi demonstrado acima, precisa ser por excelência um generalista, com uma capacidade de entender profundamente sua empresa e seu ramo de negócios, além de saber entender, manejar e criticar métodos, instrumentos de pesquisa e análise e formas de atuação de um grande número de especialistas funcionais.

Figura 4: Análise Comparativa Contadoria vs. Controladoria

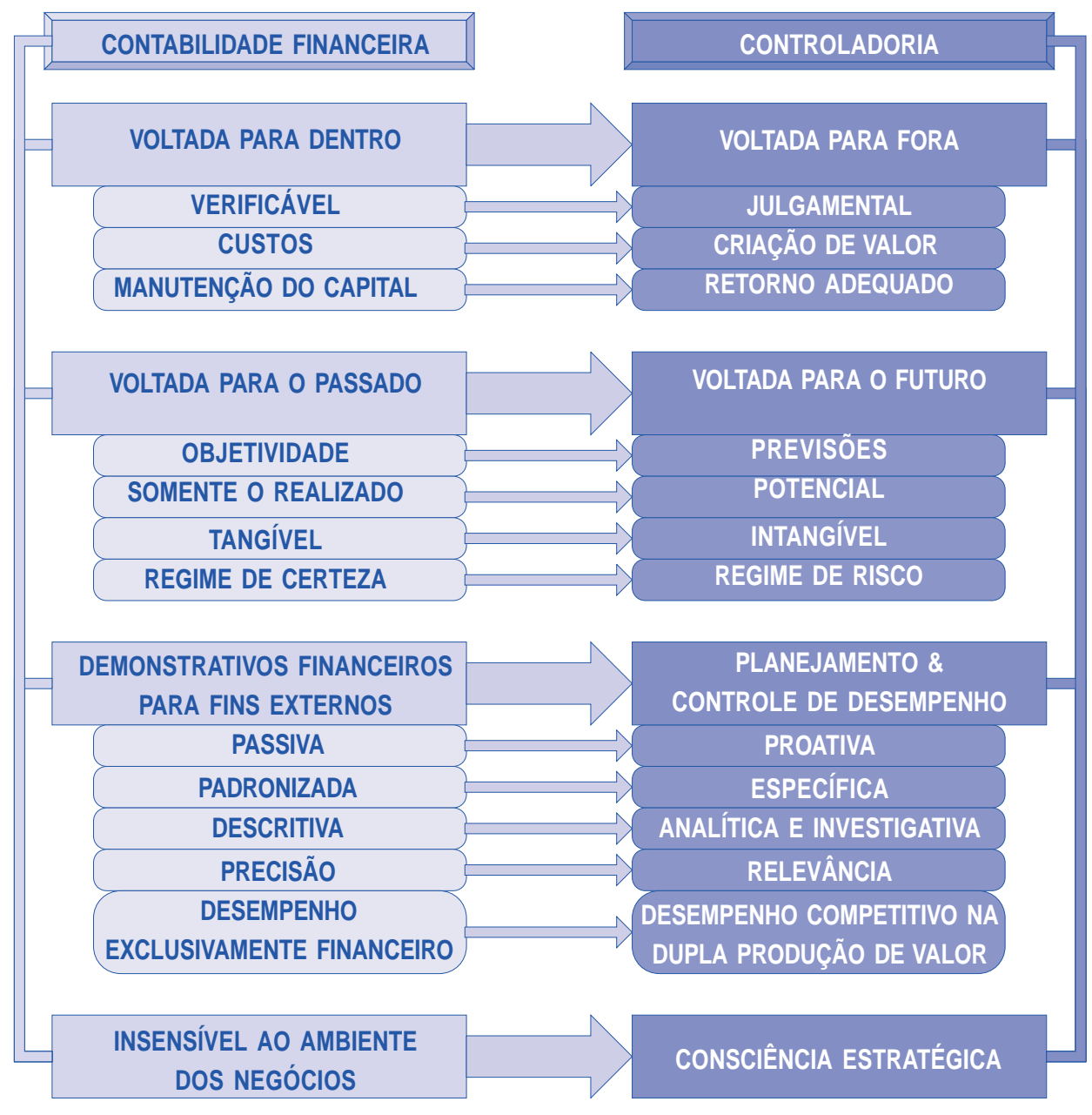

\footnotetext{
23 Num levantamento informal feito pelo autor em 27 Controladorias de grandes empresas no Brasil, apenas sete (aproximadamente $1 / 4$ delas) estão sendo comandadas por antigos contadores, apesar de que, em todas, a contabilidade financeira está incluída entre as atribuições da Controladoria (vide o Anexo 1). Na maior parte delas, onze para ser exato, o Controller é um Engenheiro (embora seis deles tivessem procurado adicionar Administração (quatro) ou Contabilidade (dois) à sua formação).
} 
Para formar um Controller, no currículo didático da área acadêmica de contabilidade deveria ser incluído, portanto, um elenco de outras disciplinas (que não seria muito grande, como pode parecer a alguns) que, a partir do modelo contábil-financeiro que teria um papel central, expandiria tal modelo ao longo dos eixos de evolução acima discutidos e formaria o núcleo básico de formação (Cano, 1994). Essas disciplinas, no seu conjunto, preparariam um profissional generalista ${ }^{24}$, cujo conhecimento estratégico, atitude crítica, base humana e diálogo inteligente com os especialistas das áreas funcionais Ihe permitiriam arquitetar o banco de dados e montar o fluxo de informações e relatórios, os quais constituiriam o grande qua- dro de avaliação do desempenho competitivo de cada empresa, que é o instrumento básico de sua governança.

Com a formação adequada e livre da "mentalidade típica do contador fiscal", um contador moderno deve considerar que o status legal atual da profissão contábil no Brasil, que lhe confere exclusividade na preparação dos demonstrativos contábeis-financeiros é, na verdade, uma grande oportunidade e uma importante "vantagem competitiva" para se promover a Controller (vide, no Anexo 1, o quadro geral das atribuições de uma moderna Controladoria, baseado em algumas grandes empresas visitadas pelo autor).

\section{BIBLIOGRAFIA CITADA ${ }^{25}$}

Adair, C. B. \& Murray, B. A., Revolução Total dos Processos, Nobel, São Paulo, 1994.

Albrecht, K., Radar Corporativo, Makron Books, 2000.

Ansoff, I., Implanting Strategic Management, PrenticeHall International, 1984.

AnupInd, R. ET AL., Managing Business Process Flows, Prentice-Hall, 1999.

Azzone, G. ET AL., "Measuring resources for supporting resource-based competition", Management Decision, V. 33, N. 9, 1995, pp. 57-62.

Best, R. J., Market-Based Management, Prentice-Hall, $2000,2^{\text {nd }}$. Edition.

Boglıol, F., La Création de Valeur, Éditions d'Organisation, 2000.

Bontempo, M. T., Análise Comparativa dos Métodos de Construção de Cenários Estratégicos no Planejamento Empresarial, dissertação de mestrado apresentada à FEAC-USP, em 1999.

Boulton, R. E. S. ET AL., Cracking the Value Code, Harper Business, 2000.

Brethauer, D. M., The Power of Strategic Costing, American Management Association, 2000.

Brimson, J. A. \& Antos, J., Activity-Based-Management, John Wiley \& Sons, 1994.

Brito, O. S., Contribuição ao Estudo do Modelo de Controladoria de Risco-Retorno em Bancos de Atacado, tese de doutorado apresentada à FEAC-Universidade de São Paulo, 2000.

Cano, N. C., A Formação do Contador como um C.F.O., Relatório ao Departamento de Contabilidade, FEAC, USP, 1994.

Cano, N. M., "A redução estratégica de custos", Revista de Contabilidade do CRC-SP, Dez/99, pg. 6/21.

CarR, D. K. ET AL., Business Process Redesign, Coopers \& Lybrand, 1992.
Churchill, G. A., Marketing Research - Methodological Foundations, The Dryden Press, 1999, $7^{\text {th }}$ Edition.

Cleland, A. S. \& Bruno, A. V., The Market Value Process, Jossey-Bass Publishers, 1996.

Cokıns, G., Activity-Based Cost Management, Irwin, 1996.

Collins, D.J. \& Montgomery, C.A., "Competing on resources", Harvard Business Review, Jul/Aug, 1995, pp. 118/128.

Culp, C. L., The Risk Management Process, John Wiley \& Sons, 2001.

Daniel, M. H., World of Risk, John Wiley \& Sons, 2000.

Davenport, T. H., Process Inovation: Reengineering Work Through Information Technology, Harvard Business School Press, 1993.

DoherTy, N. A., Integrated Risk Management, McGraw Hill, 2000.

Donleavy, G. D., Cash Flow Accounting, Routledge, 1994.

Drucker, P. F., Management: Tasks, Responsibilities, Practices, Harper Business, 1993.

Drucker, P. F., Managing for Results, Harper \& Row Publishers, 1964.

Eccles, R. G. ET AL., The Value Reporting Revolution, J. Wiley \& Sons, 2001.

Enriquez, E., A Organização em Análise, Vozes, 1997.

Foss, N. J., Editor, Resources, Firms and Strategies, Oxford University Press, 1997.

Franks, R., Implementing an Accounting System - a Practical Guide, Kogan Page, 1995, Revised Edition.

George, A. M., Protecting Shareholder Value, Richard D. Irwin, 1996.

Godet, M., Prospective et Planification Stratégique, Economica, 1985.

Goldberg, J. \& Nitzsch, R. von, Behavioral Finance, J. Wiley \& Sons, 2001.

Grant, R. M., Contemporary Strategy Analysis, Basil Blackwell, 1991.

\footnotetext{
${ }^{24}$ Seria, na verdade, o único generalista funcional da empresa.

$25 \mathrm{O}$ autor reuniu uma vasta bibliografia composta de livros, artigos, atas de conferência e até relatórios internos, que lhe foram cedidos por empresas. Pela sua extensão e, em alguns casos, pela exigência de sigilo, tal bibliografia não pode ser inteiramente citada. Ficou, então, limitada aos livros e artigos mais importantes. O autor pede desculpas a todos que contribuíram tão generosamente para sua pesquisa por nem sempre terem suas opiniões ou seus trabalhos citados expressamente.
} 
GreideR, W., One World, Ready or Not, Simon \& Schuster, 1998.

Griego Jr., P. L. \& Pilachowski, M., Activity-Based Costing, PT Publications, 1995.

Harrington, H. J., Total Improvement Management, McGraw-Hill, 1995.

Hatherly, D., Accounting for Business Activity, Pitmann Publishing, 1993.

Hirst, P. \& Thompson, G., Globalization in Question, Polity Press, 1997.

Hitт, M. A. Eт AL., Strategic Management - Competitiveness and Globalization, South-Western College Publishing, 2000, $4^{\text {th }}$ Edition.

ifaC-International Federation of Accountants, The Management

Accounting for the Year 2004, IFAC, August, 2000.

IFAC-International Federation of Accountants, $A$ Profession Transforming: from Accounting to Management (Study 11), IFAC, March, 2001.

Jensen, M., "The modern industrial revolution, exit, and the failure of internal control systems", in Studies in International Corporate Finance and Governance Systems, Chew, D. H. (Editor), Oxford University Press, 1997.

Johansson, N. J. et AL., Business Process Reengineering, John Wiley \& Sons, 1993.

Kaplan, R. S. \& Norton, D. P., The Balanced Scorecard, Harvard Business School Press, 1996.

Kaplan, R. S. \& Norton, D. P., The Strategy-Focused Organization, Harvard Business School Press, 2001.

KeIDeL, R. W., Seeing Organizational Patterns, BerrettKoehler Publishers, 1995.

Kilmann, R. \& Kilmann, I., Making Organizations Competitive, Jossey-Bass Publishers, 1991.

KNIGHT, J. A., Value Based Management, McGraw Hill, 1998.

Kоск, S., "Implementation considerations for activity-based cost systems in service firms", Management Decision, V. 33, N. 6, 1995, pp. 57-63.

Koller, G., Risk Modeling for Determining Value and Decision Making, Chapmann \& Hall/CRC, 2000.

Lev, B., Intangibles: Management, Measurement and Reporting, Brookings Institution Press, 2001.

Liautaud, B., E-Business Inteligence, McGraw-Hill, 2000.

MACE, M. L., Directors: Myth and Reality, Harvard Business School Press, 1986

Maklan, S. \& Knox, S., Competing on Value, Pitmann Publishing, 1998.

Malmotra, N. K., Marketing Research, Prentice-Hall, 1999, $3^{\text {rd }}$ Edition.

Marques, Antonio C. F., Deterioração Organizacional, Makron Books, 1994.

Martin, J. D. \& Petty, J. W., Value Based Management, Harvard Business School Press, 2000.

McTaggart, J. M. Et AL., The Value Imperative, The Free Press, 1994.

MintzBerg, H., Mintzberg on Management, The Free Press, 1989.

MintzBerg, H., Estrutura e Dinâmica das Organizações, Publicações Don Quixote, Lisboa, 1995.

ModIs, T., Conquering Uncertainty, McGraw Hill, 1998.

Morgan, G., Organizations in Society, Macmillan Education
Ltd., 1990.

Morris, D. \& Brandon, J., Reengineering Your Business, McGraw Hill, 1993.

Neves, N. J. O. \& Fagundes, M., Mais Lucros com Menos Impostos, Mission Desenvolvimento Organizacional, 1999.

Paine, F.T. \& Naumes, W., Organizational Strategy and Policy, Holt-Saunders International Editions, $3^{\text {rd }}$ Edition, 1982.

Parolinı, C., The Value Net, John Wiley Books, 1999.

PARR, R. L., Investing in Intangible Assets, John Wiley \& Sons, 1991.

PeopleSoft O Mais Importante Banco de Dados Empresarial, PeopleSoft, Conferência, São Paulo, Agosto de 1999.

Pearce J. A.\& Robinson Jr., R. R., Formulation, Implementation and Control of Competitive Strategy, Irwin, 1997, $6^{\text {th }}$ Edition.

Pickford, J., Editor, Mastering Risk: 1 - Concepts, Prentice-Hall, 2001.

Porter, M., Vantagem Competitiva, Campus, 1989.

Prahalad, C. K., "Corporate Governance or Corporate Value Added? Rethinking the Primacy of Shareholder Value" in Studies in International Corporate Finance and Governance Systems; Chew, D. H., Editor, Oxford University Press, 1997.

Rav, D., Mésurer et Développer la Satisfaction des Clients, Éditions D'Organisation, 2001.

Reekie, W. D. et al., The Economics of Modern Business, Blackwell, 1991, $2^{\text {nd }}$.

Ringland, G., Scenario Planning - Managing for the Future, John Wiley \& Sons, 1998.

Robert, M., Strategy Pure \& Simple II, McGraw-Hill, 1997.

Rummler, G. A \& Brache, A. P., Improving Performance, Joshey-Bass Publishers, 1990.

Rust, R.T., O Valor do Cliente, Bookman, Porto Alegre, 2001.

Scotr, M. C., Value Drivers, John Wiley \& Sons, 1998.

Shank, J. K. \& Govindarajan, V., Strategic Cost Management, The Free Press, 1993.

Shleifer, A., Inefficient Markets, Oxford University Press, 2000.

Strwotzky, A. J., Migração do Valor, Campus, Rio de Janeiro, 1997.

Sмıтн, D. K., Make Success Measurable, John Wiley \& Sons, 1999.

Stewart III, G. B., The Quest for Value, HarperBusiness, 1991.

Szimanski, D. M. \& Henard, D. H., "Customer satisfaction: a meta-analysis of the empirical evidence", Journal of the Academy of Marketing Science, V. 29, N. 1, 2001, pp. 16-35.

TaVAres, M. C. \& Fiori, J. L., Desajuste Global e Modernização Conservadora, Paz e Terra, 1993.

Thakor, A. V., Becoming a Better Value Creator, JosseyBass, 2000

Tinoco, J. E. P., Balanço Social, Editora Atlas, 2001.

Tucker, R. B., Agregando Valor ao Seu Negócio, Makron Books, 1999.

Tuominen, K., Managing Change, ASQ Quality Press, 2000.

Watson, G. H., Business System Reengineering, John Wiley \& Sons, 1994

Youna, P. C. \& Tippins, S. C., Managing Business Risk, American Management Association, 2001. 


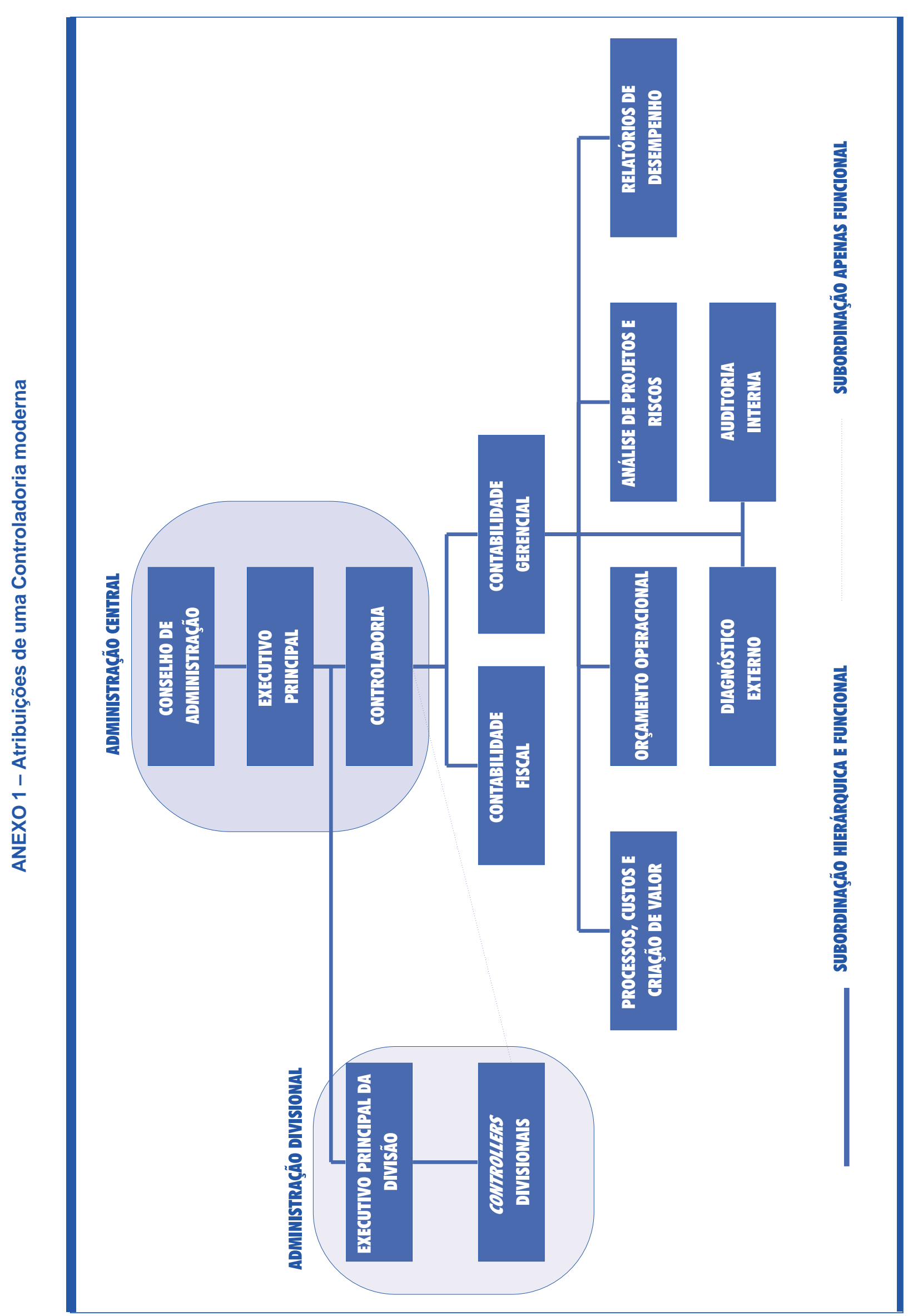

• Revista Contabilidade \& Finanças - USP, São Paulo, n. 28, p. 7 - 28, jan./abr. 2002 